\title{
Cerebral lupus erythematosus responding to plasmaphaeresis
}

\author{
D. T. P. Evans* \\ M.B., M.R.C.P.(U.K.) \\ D. J. de L. HoRnE $\ddagger$
M.Phil., Ph.D.
}

A. Riglar

M.Sc.

\author{
M. GILES $\dagger$ \\ M.B., Ph.D.
}

\author{
A. J. F. d'APICE $\dagger$ \\ M.B., M.D., F.R.A.C.P. \\ B. H. ТоH§ \\ M.B., Ph.D., F.R.A.C.P.
}

\begin{abstract}
*Clinical Research Unit, The Walter and Eliza Hall Institute of Medical Research, †Departments of Psychiatry and Nephrology, The Royal Melbourne Hospital, $\ddagger$ Department of Psychiatry, University of Melbourne, $\S$ Department of Pathology and Immunology, Monash University Medical School, and $\Psi_{\text {Department of Medicine, }}$ Austin Hospital
\end{abstract}

\begin{abstract}
Summary
A 44-year-old nurse with a 12-year history of systemic lupus erythematosus developed a schizophrenialike psychosis due to cerebral lupus. Prednisolone in doses up to $200 \mathrm{mg}$ daily was ineffective. Levels of immune complexes by the Raji cell assay were greatly increased in serum and cerebrospinal fluid. Plasma exchange was performed on 4 occasions over 4 days. Three days later, there was a marked and sustained improvement in the mental state, the psychosis resolved and tests of psychological function and electroencephalographic abnormalities improved. There was a corresponding decrease in levels of immune complexes and in titres of anti-neuronal antibody. Five months later, several serological indices had risen to pre-plasmaphaeresis levels except for the level of immune complexes. The patient remained in clinical remission. This case provides further evidence that high levels of circulating immune complexes may be a determinant of cerebral lupus and that plasmaphaeresis may be of lasting benefit in this disease.
\end{abstract}

\section{Introduction}

Systemic lupus erythematosus (SLE) is an autoimmune disease attributable in a large part to deposition or formation in the tissues of immune complexes. Plasma exchange has been used in immune complex-mediated glomerulonephritis (Becker et al., 1977; Dunadio, 1977) to reduce levels of circulating immune complexes, and mediators of tissue injury such as complement components and

Correspondence: Dr I. R. Mackay, The Walter and Eliza Hall Institute of Medical Research, Post Office, Royal Melbourne Hospital, Victoria, 3050, Australia. procoagulants. Rossen et al. (1977) described a patient with SLE, with renal and cerebral involvement, in whom treatment with cyclophosphamide, prednisolone and repeated plasma exchange led to neurological remission and reduction in circulating immune complexes. However, in another case of cerebral lupus with a normal serum level of immune complexes, a plasma exchange up to 18.6 litres produced no improvement (Verrier-Jones et al., 1978). In a patient with SLE and a schizophreniform psychosis, reduction by plasmaphaeresis of high levels of circulating immune complexes and anti-neuronal antibody induced rapid and sustained improvement.

\section{Case report}

The patient developed SLE in 1967 at the age of 32 , and had been treated intermittently with prednisolone. Disease activity continued with episodes of episcleritis, giant urticaria, diarrhoea, colic and erythematous rashes. In December 1978, when prednisolone had been withdrawn for 3 months, her husband noted a change in mood and personality and thereafter there were periods of irrational uncharacteristic thought and behaviour. In March 1979 , prednisolone $10 \mathrm{mg}$ per day was recommenced; however, the mental symptoms persisted, and she was treated with trifluoperazine, chlorpromazine, and benztropine to control her psychosis.

She was admitted to the Clinical Research Unit in March 1979. The only abnormal physical findings were moderate alopecia and an erythematous macular rash on the face and upper trunk. She was dishevelled, restless and showed inconstant disorientation in time and place. There was pressure of 
speech with grandiose and delusional content. Mood was elevated. She showed thought disorder characterized by derailment, loosening of association and interpenetration of personal themes. She also complained of gustatory hallucinations. There was gross impairment of attention and concentration and to a lesser extent short-term memory, but remote memory was relatively intact. An electroencephalogram was abnormal, whilst a CAT brain scan was normal.

There was no improvement with large doses of neuroleptic drugs including thioridazine, chlorpromazine, and haloperidol. Prednisolone in doses up to $200 \mathrm{mg}$ daily was equally ineffective. The lack of response to the combination of anti-psychotic drugs and high doses of prednisolone prompted treatment by plasmaphaeresis, on days 35-38 after admission.

Investigations showed $\mathrm{Hb} 11.6 \mathrm{~g} / \mathrm{dl} ; \mathrm{ESR}$ $80 \mathrm{~mm} / \mathrm{hr}$ (Westergren); WBC $11.8 \times 10^{9} / 1$ and lymphocytes $0.95 \times 10^{9} / 1$; serum iron, $6.6 \mu \mathrm{mol} / \mathrm{l}$. The HLA phenotype was Al, A3 : B7, B8. Serum IgG was normal, but was increased in the cerebrospinal fluid (CSF) $(0.06 \mathrm{~g} / 1$; normal $<0.03 \mathrm{~g} / \mathrm{l})$. The LE cell test was positive, the titre of anti-nuclear antibody by immunofluorescence was $1: 1000$, the level of anti-DNA binding activity (see Methods) was $340 \mathrm{u} . / \mathrm{ml}$ (normal $<25 \mathrm{u} . / \mathrm{ml}$ ), and the levels of serum complement components were serum C3, $53 \mathrm{mg} / \mathrm{dl}$ and serum $\mathrm{C} 4,30 \mathrm{mg} / \mathrm{dl}$. Immune complexes were extremely high in serum, >3000 and $1610 \mu \mathrm{g} / \mathrm{ml}$ of aggregated gamma globulin equivalent per $\mathrm{ml}$ on 2 occasions (normal $0-40 \mu \mathrm{g}$ ) and also in CSF, $80 \mu \mathrm{g} / \mathrm{ml}$ (mean for controls, 8.85 $\mu \mathrm{g} / \mathrm{ml})$.

\section{Methods}

\section{Immune complexes}

Immune complexes were assayed in serum and cerebrospinal fluid by 3 methods. The Raji cell radioimmunoassay was performed by the method of Theofilopoulos, Wilson and Dixon (1976), except that $0.25 \mu \mathrm{g}{ }^{125} \mathrm{I}$-labelled protein $\mathrm{A}$ in $50 \mu \mathrm{l}$ of medium was used in the final incubation instead of ${ }^{125} \mathrm{I}$ rabbit anti-human IgG.

Because sera from patients with SLE react in the Raji cell radioimmunoassay after ultracentrifugation, presumably owing to antibody reactive with the Raji cell surface, all sera for this assay were tested before and after ultracentrifugation with the difference representing the true level of immune complexes (A. G. Riglar and I. F. C. McKenzie, in preparation).

The Clq binding assay for immune complexes was performed by the method of Nydegger et al. (1974) and Zubler and Lambert (1977), and the polyclonal rheumatoid factor assay by the method of Cowdery, Treadwell and Fritz (1975).

DNA binding activity was measured with the
Standard Anti-DNA Kit (Amersham, Bucks, ֶ England). Anti-neuronal autoantibody was tested 3 for by indirect immunofluorescence with viable $\varrho$ monolayer cultures of mouse neuroblastoma cells. $c$ (neuro-2a, Flow Laboratories) as described by Toh $\overrightarrow{\overrightarrow{\mathrm{s}}}$ and Mackay (1981). For immunofluorescent tests, the cells were subcultured on glass coverslips in $35-\mathrm{mm}$ culture dishes and incubated for $24-72 \mathrm{hr}$ at $37^{\circ} \mathrm{C}$ and rinsed in buffer.

Bound immunoglobulin was detected with $\stackrel{\overline{2}}{\circ}$ FITC-labelled goat anti-human immunoglobulin. Allos tests were carried out in parallel with PBS and nor- $\overrightarrow{0}$ mal human serum controls. The immunoglobulin $\overrightarrow{-}$ class of the sera was determined by the tests with $\vec{\rho}$ FITC-labelled goat anti-human IgG, IgA or IgM.

\section{Plasmaphaeresis}

This was performed using an Amminco continuous. flow centrifuge (Americal Instrument Company,, Silver Spring, Maryland). The replacement solution is was Stable Protein Plasma Solution (SPPS).

\section{Results}

\section{Clinical observations}

Four 4-litre plasma exchanges were given, further음 exchanges being precluded by the occurrence of $\mathrm{a}$ left lower lobar Klebsiella pneumonia. Three da $8 s_{\infty}^{\circ}$ after the fourth plasma exchange, there was a marked. improvement in the mental state with resolution 1 fo the psychosis, insight into the nature of the illnesss and loss of disorientation. After 4 weeks, improvement was maintained, the dose of prednisolone hado been reduced to $15 \mathrm{mg}$ daily and all psychotropice drugs had been withdrawn. An electro-encephalo- $\overrightarrow{0}$ gram which had shown irregular activity of 7-8을 cycles per second with moderate excess of thetaactivity became normal after plasma exchange.

\section{Laboratory studies}

After plasmaphaeresis, there was an immediateo fall to zero in the serum level of immune complexes by the Raji cell assay, with no increase for 60 daysô (Table 1). The maximum level after plasmaphaeresis 3 was $250 \mu \mathrm{g} / \mathrm{ml}$, recorded after 138 days. Assays foro immune complexes by binding to $\mathrm{Clq}$ and to poly $\rightarrow$ clonal rheumatoid factor showed only slight ande. unsustained reductions after plasma exchange.

Serum DNA binding antibody levels 2 days ${ }^{\mathrm{N}}$ after plasmaphaeresis had fallen from $128-340 \mathrm{u} . / \mathrm{ml}, \mathbb{O}$ and the maximum level after plasmaphaeresis was స్ట $37 \mathrm{u} . / \mathrm{ml}$.

The titre of anti-neuronal antibody fell fromo 80-160 to undetectable levels on the second day of plasma exchange, but thereafter increased gradually. until pre-plasmaphaeresis levels were reached evento though there were no overt neurological abnormalities. 
TABLE 1. Serial changes in serum immune complexes ( 3 assays), DNA binding antibody and anti-neuronal antibody titres with time. Plasmaphaeresis performed on $26 / 4 / 79-29 / 4 / 79$ inclusive

\begin{tabular}{|c|c|c|c|c|c|c|}
\hline Date of serum sample & $\begin{array}{l}\text { Days after } \\
\text { admission }\end{array}$ & $\begin{array}{c}\text { Assays for } \\
\text { Raji assay } \\
(\mu \mathrm{g} / \mathrm{ml})\end{array}$ & $\begin{array}{l}\text { ne complexes } \\
\text { ClqBA } \\
(\mu \mathrm{g} / \mathrm{ml})\end{array}$ & PRFA & $\begin{array}{l}\text { DNA binding } \\
\text { antibody } \\
(\mathrm{u} . / \mathrm{ml})\end{array}$ & $\begin{array}{l}\text { Anti-neuronal } \\
\text { antibody } \\
\text { titres }\end{array}$ \\
\hline $\begin{array}{r}2 / 4 / 79 \\
5 / 4 / 79 \\
17 / 4 / 79 \\
23 / 4 / 79 \\
26 / 4 / 79 \\
27 / 4 / 79 \\
28 / 4 / 79 \\
29 / 4 / 79\end{array}$ & $\begin{array}{l}11 \\
14 \\
26 \\
32 \\
35 \\
36 \\
37 \\
38\end{array}$ & $\begin{array}{r}>3000 \\
1610 \\
1200 \\
\\
1600 \\
395 \\
14 \\
0\end{array}$ & $\begin{array}{l}0.5 \\
0.5 \\
\\
0.5 \\
0.1 \\
0.1 \\
0.1\end{array}$ & $\begin{array}{l}0.6 \\
0.7 \\
\\
0.9 \\
0.4 \\
0.4 \\
0.3\end{array}$ & $\begin{array}{l}340 \\
380 \\
230 \\
128\end{array}$ & $\begin{array}{r}160 \\
80 \\
80 \\
\\
\\
<5 \\
10 \\
<5\end{array}$ \\
\hline $\begin{array}{l}\text { Post-plasmaphaeresis } \\
1 / 5 / 79 \\
9 / 5 / 79 \\
15 / 5 / 79 \\
21 / 5 / 79 \\
30 / 5 / 79 \\
28 / 6 / 79 \\
14 / 9 / 79 \\
17 / 10 / 79 \\
28 / 5 / 80\end{array}$ & $\begin{array}{r}40 \\
48 \\
54 \\
60 \\
69 \\
98 \\
176 \\
209 \\
433\end{array}$ & $\begin{array}{r}160 \\
0 \\
32 \\
0 \\
0 \\
250 \\
115 \\
46\end{array}$ & $\begin{array}{l}0.2 \\
0.2 \\
0.2 \\
0.7 \\
0.9\end{array}$ & $\begin{array}{l}0.4 \\
0.5 \\
\\
0.4 \\
0.7 \\
0.6\end{array}$ & $\begin{array}{l}13 \\
32 \\
30 \\
28 \\
38\end{array}$ & $\begin{array}{r}5 \\
160 \\
160 \\
160 \\
160\end{array}$ \\
\hline Normal & & $<40$ & $<1.0$ & $<1.7$ & $<25$ & \\
\hline
\end{tabular}

TABLE 2. Psychological test results

\begin{tabular}{|c|c|c|c|c|}
\hline & $\begin{array}{l}\text { Before plasmaphaeresis } \\
\text { ( } 3 \text { days before) }\end{array}$ & $\begin{array}{l}\text { After plasmaphaeresis } \\
\text { (12 days after) }\end{array}$ & $\begin{array}{c}\text { Follow-up } \\
\text { (23 days after) }\end{array}$ & \\
\hline Mill Hill vocabulary test IQ & 105 & 103 & 114 & \\
\hline Standard progressive matrices IQ & $<75$ & - & 84 & . \\
\hline $\begin{array}{l}\text { Benton visual retention test } \\
\text { (i) Correct } \\
\text { (ii) Expected correct }\end{array}$ & $\begin{array}{l}2 \\
8\end{array}$ & - & $\begin{array}{l}4 \\
8\end{array}$ & \\
\hline Wechsler memory scale IQ & 73 & 92 & 90 & $\cdot$ \\
\hline $\begin{array}{l}\text { WMS subtest raw scores } \\
\text { Current information } \\
\text { Orientation } \\
\text { Mental control } \\
\text { Logical memory } \\
\text { Digit span } \\
\text { Design memory } \\
\text { Verbal associate learning }\end{array}$ & $\begin{array}{r}2 \\
1 \\
7 \\
1 \\
9 \\
6 \\
13\end{array}$ & $\begin{array}{r}4 \\
4 \\
7 \\
8 \\
10 \\
4 \\
15\end{array}$ & $\begin{array}{r}4 \\
5 \\
8 \\
7 \\
9 \\
7 \\
10\end{array}$ & 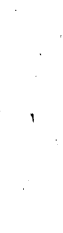 \\
\hline
\end{tabular}

\section{Psychological tests}

Psychological test results (Table 2) indicated that before treatment, orientation for time and place was markedly impaired. Short-term memory was severely impaired although short-term concentration was normal. Verbal Associate Learning was performed well.

Two days after the last plasmaphaeresis she became rational and co-operative and fully orientated in time and space. She showed some insight into her illness and spontaneously recognized her previous poor compliance with medication. This improve ment was maintained and 8 days after plasmaphaeresis she demonstrated a good understanding of current affairs, considerable improvement in memory, could perform serial sevens accurately, continued to have no delusions, and.showed good short-term memory and registration to informal testing. She was able to interpret proverbs well, and correctly remembered the Babcock sentence. Formal psychological testing was done before plasmaphaeresis and 12 and 23 days after the last treatment. The changes 


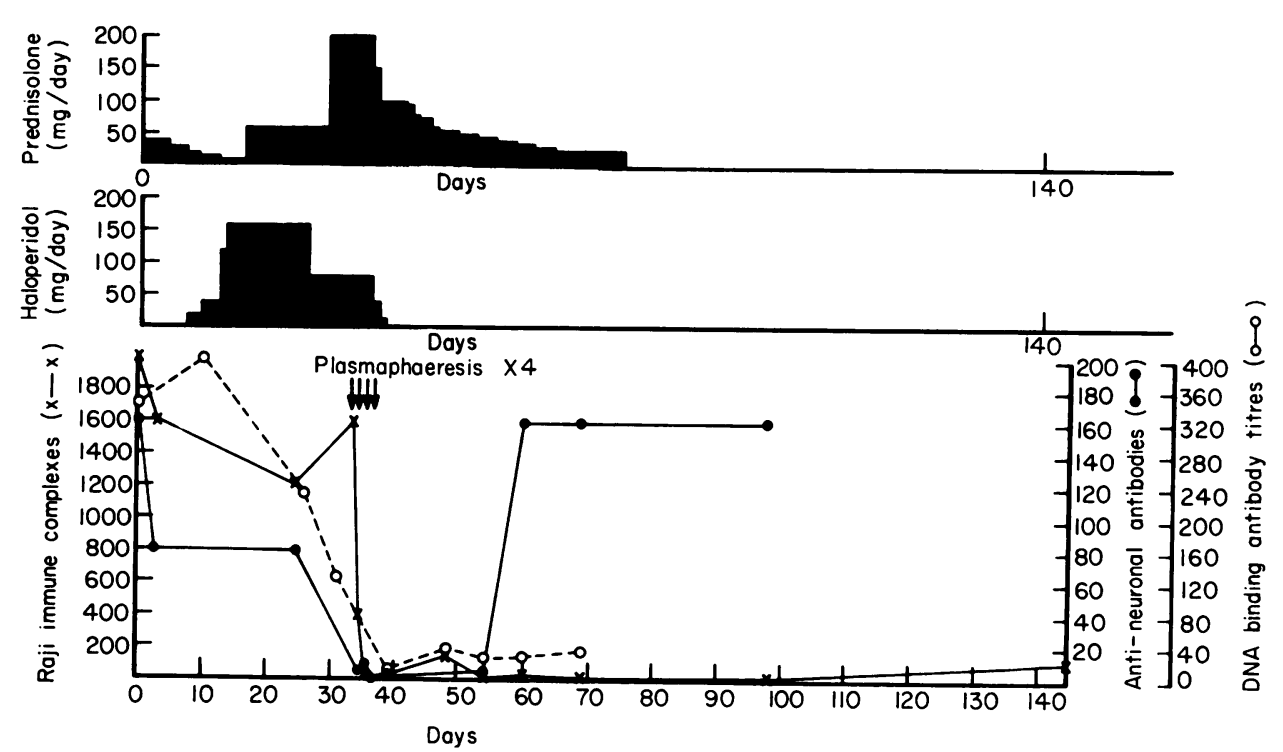

FIG. 1. Graph of immune complexes (Raji assay), DNA binding antibody and anti-neuronal antibody titres before and after plasmaphaeresis. Also charted are prednisolone and haloperidol dosage.

observed indicated localized cortical dysfunction and documented the significant improvement which followed plasmaphaeresis (Table 2). At follow-up 9 weeks later, improvement in mental state was maintained and she had returned to her previous active life. At the time of her follow-up in October 1980 she was still well.

\section{Discussion}

The patient described fulfilled the criteria for diagnosis of SLE proposed by the American Rheumatism Association (ARA) in 1971 (Editorial, 1975 ) in that 6 of the 14 specified criteria were present.

She had an organic psychosis and the diagnosis of cerebral lupus was made on the basis of neuropsychiatric features occurring in a patient with established SLE (having excluded effects of corticosteroids or other agents), EEG changes, a raised level of IgG, and increased anti-DNA binding activity in the cerebrospinal fluid. The level of CSF cyclic GMP, which has been correlated with neuropsychiatric manifestations of SLE (Kassan and Kagen, 1978) was not measured in the present case.

The pathogenesis of cerebral lupus is uncertain. There is evidence for the presence in CSF of antineuronal antibodies which are either specific for neuronal antigens or are cross-reactive with lymphocyte antigens (Bresnihan et al., 1979). However, the data of Winfield, Brunner and Koffler (1978) do not support direct involvement of either DNA/anti- $\vec{\bullet}$ DNA complexes, or of lymphocytotoxic antibodio $s \stackrel{\infty}{-}$ cross-reactive with brain cells.

Post-mortem studies have shown deposits of in⿳亠二口犬 munoglobulins and complement within the choroid plexus, and it has been suggested that deposits of immune complexes within the choroid plexus may $\frac{\mathrm{Q}}{\mathrm{O}}$ affect permeability sufficiently to allow circulating $\stackrel{2}{\rightarrow}$ anti-neuronal antibody access to cerebral tissues (Atkins et al., 1972). Immunofluorescent tests for anti-neuronal antibodies on the patient's sera showed a dramatic drop in antibody titres after plasma-

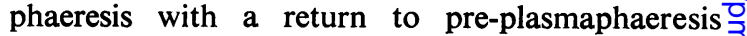
levels after 3 weeks. The observations that the patient has remained asymptomatic and that the levels of the 3 Raji assay immune complexes have remained depressed suggest that both elevated immune $\frac{\circ}{3}$ complex levels and anti-neuronal antibodies are necessary for the development of cerebral lupus. The data are consistent with the suggestion that the $\frac{D}{0}$ blood brain barrier needs to be breached by immune complex-mediated cerebral vasculitis before anti- $\mathcal{N}$ neuronal antibodies can penetrate the brain. Anti- $N$ neuronal antibodies, cytotoxic for neuroblastoma cell lines, demonstrated by immunofluorescence, $\omega$ have also been reported by others (Wilson et al., 1979; Bluestein, 1978).

There is evidence for the presence of Fc receptors $\mathscr{D}$ in normal human choroidal tissue (Braathen and Førre, 1980). These receptors may bind K-cells producing damage via the classical complement 
pathway; alternatively, they may bind immune complexes which block the choroid plexus. Exacerbation of cerebral lupus being associated with raised levels of immune complexes in the CSF has not been previously reported.

Plasmaphaeresis in SLE is being increasingly used (Leading Article, 1979) and the indications for plasmaphaeresis in cerebral lupus are becoming clearer. A favourable response can be anticipated if there are high levels in serum of immune complexes and antibodies to double-stranded DNA before treatment (Rossen et al., 1977; Verrier-Jones et al., 1978) and, as judged from the present case, high levels in CSF of immune complexes may be a predictor of benefit.

Documenting the changes in mental state in cerebral lupus, and improvements or otherwise as a response to a particular treatment is difficult owing to the need to quantify what is usually a subjective assessment, and psychological testing was undertaken to provide a basis for objective assessment in the present patient. That the improvement in mental state was due to plasmaphaeresis rather than the antipsychotic medication seems very likely in view of the temporal relationship between plasmaphaeresis and the improvement in mental state, the lack of response before plasmaphaeresis and the fact that response to anti-psychotic medication is usually more gradual than in the present case. It might be informative to perform isotope ${ }^{15} \mathrm{O}_{2}$ or xenon brain scans before and after plasmaphaeresis.

The beneficial mechanisms attributable to plasmaphaeresis remain speculative. In the short term there is presumably a reduction of the agent(s), antineuronal antibodies or immune complexes, which determine the pathogenesis of cerebral lupus. The long-term benefit, exemplified by the present case, may be attributable to abrogation of the process of autoimmune amplification described by Hall et al. (1977). Finally this case suggests that shorter than conventional courses of plasma exchange may be effective in ameliorating the course of SLE.

\section{Acknowledgment}

I am very grateful to Dr I. R. Mackay for permission to report this case and also for patient advice and encouragement with the text. I am also grateful for the advice of Prof. B. Davies, Dept of Psychiatry, Royal Melbourne Hospital, and Dr D. C. Cowling, Director of Haematology of that hospital, and members of that department for the anti-DNA analyses.

\section{References}

Atkins, C.J., Kondon, J.J.R., Quismorio, F.P. \& Friou, G.J. (1972) The choroid plexus in systemic lupus erythematosus. Annals of Internal Medicine, 76, 65.
Becker, G.J., D'APICE, A.J.F., WALKer, R.G. \& KincaidSMITH, P. (1977) Plasmapheresis in the treatment of glomerulonephritis. Medical Journal of Australia, 21, 693.

Bluestein, H.G. (1978) Neurocytotoxic antibodies in serum of patients with systemic lupus erythematosus. Proceedings of the National Academy of Sciences of the United States of America, 75, 3965.

BraAthen, L.R. \& FørRe, Ø. (1980) Receptors for IgG in human choroid plexus. Clinical Immunology and Immunopathology (in press).

Bresnihan, B., Oliver, M., Williams, B. \& Hughes, G.R.V. (1979) An anti-neuronal antibody cross-reacting with erythrocytes and lymphocytes in systemic lupus erythematosus. Arthritis and Rheumatism, 22, 312.

Cowdery Jr, J.S., Treadwell, P.E. \& Fritz, R.B. (1975) A radioimmunoassay for human antigen-antibody complexes in clinical material. Journal of Immunology, 114, 5.

DuNADIO, J.V. (1977) Treatment of lupus nephritis. Nephron, 19, 186.

EdITORIAL (1975) Criteria for Classification of Systemic Lupus Erythematosus. Journal of the American Medical Association, 231, 846.

Hall, C.L., Colvin, R.B., Carey, L. \& McCluskey, R.T. (1977) Passive transfer of autoimmune disease with isologous $\mathrm{IgG}_{1}$ and $\mathrm{IgG}_{2}$ antibodies to the tubular basement membrane in strain XIII guinea-pigs. Journal of Experimental Medicine, 146, 1246.

KASSAN, S.S. \& KAGEN, L.J. (1978) Cerebrospinal fluid cyclic GMP and other clinical markers of disease activity in central nervous systemic lupus erythematosus. Arthritis and Rheumatism, 21, 568.

Leading Article (1979) Plasmapheresis and severe glomerulonephritis. British Medical Journal, 1, 434.

Nydegger, V.E., Lambert, P.H., Gerber, H. \& Meischer, P.A. (1974) Circulating immune complexes in the serum in systemic lupus erythematosus and in carriers of hepatitis B antigen: quantitation by binding to radiolabelled $\mathrm{Clq}$. Journal of Clinical Investigation, 54, 297.

Rossen, R.D., Hersh, E.M., Sharp, J.T., McCredie, K.B., Gyorkey, F., SUKI, W.N., EknOyan, G. \& ReisberG, M.S. (1977) Effect of plasma exchange on circulating immune complexes and antibody formation in patients treated with cyclophosphamide and prednisone. American Journal of Medicine, 63, 674.

Theofilopoulos, A.N., Wilson, C.B. \& Dixon, F.J. (1976) The Raji cell immunoassay for detecting immune complexes in human sera. Journal of Clinical Investigation, 57, 169.

ToH, B.H. \& MACKAY, I.R. (1981) Auto-antibody to a novel neuronal antigen in systemic lupus erythematosus and in normal human sera. Clinical and Experimental Immunology (in press).

VERRIER-JONES, J., RoBINSON, M.F., LAYFER, L.F. \& MCLEOD, B. (1978) Plasmapheresis in systemic lupus erythematosus: correlation of response with level of immune complexes measured by Raji-cell assay. Arthritis and Rheumatism, 20, 562.

Wilson, H.A., Winfield, J.B., LAhitA, R.G. \& Koffler, D. (1979) Association of IgG anti-brain antibodies with central nervous system dysfunction in systemic lupus erythematosus. Arthritis and Rheumatism, 22, 458.

Winfield, J.B., BRunNer, C.M. \& Koffler, D. (1978) Serological studies in patients with systemic lupus erythematosus and central nervous system dysfunction. Arthritis and Rheumatism, 21, 289.

ZubleR, R.H. \& LAMBerT, P.H. (1977) Recent Advances in Clinical Immunology. First edn, Chapter 6, p. 131. Churchill Livingstone. 